The most prevalent polymorphism (84,6\% (IC95\%: 84,09\%-85,11\%) and in cases (86,0\% (IC95\%: 79,43\%-92,57\%) was homozygous CC (ITPase-c94a); in controls homozygous GG (GGH-T401C) (87,5\% (IC95\%:81,58\%-93,42\%)

There were no significant differences in the parameters of activity between groups, in both, patients were best basally controlled than at the start of the MTX income and/or bDMARD

Being homozygous-AA for the DHFR gene was significantly associated $(p<0.05)$ with the appearance of AE (none of the 4 homozygous AA patients for that gene had $\mathrm{AE}$ )

In MLR, homozygous GG (ref. heterozygous AG) in polymorphism GGH-T401C, being homozygous CC (ref. heterozygous TC) in polymorphism ABCC2-C24T and PCR $(\mathrm{mg} / \mathrm{dL})$ at the start of bDMARD resulted independent predictive factors of MTX intolerance

Conclusion: Polymorphisms T401C for the GGH gene and C24T for the ABCC2 gene and PCR at the start of the bDMARD resulted independent predictive factors of MTX intolerance

. Polymorphism homozygous AA for DHFR gene was related to significant protection against appearance of $A E$

Disclosure of Interests: Alejandro Escudero Contreras: None declared, Rafaela Ortega Castro: None declared, Jerusalem Calvo Gutierrez: None declared, Natalia Mena-Vázquez: None declared, Rafael Cáliz Cáliz: None declared, Eduardo Collantes Estevez Grant/research support from: ROCHE and Pfizer, Speakers bureau: ROCHE, Lilly, Bristol and Celgene, Antonio Fernandez-Nebro: None declared, Maria del Carmen Abalos-Aguilera: None declared, Chary Lopez-Pedrera Grant/research support from: ROCHE and Pfizer., $\mathrm{M}^{\mathrm{a}}$ Teresa Ruiz Jimenez Employee of: Roche Farma, SPAIN, Font Ugalde Pilar: None declared

DOI: 10.1136/annrheumdis-2020-eular.3258

\section{AB0339 2 THE IMPORTANCE OF THERAPEUTIC COMPLIANCE ADHERENCE TO METHOTREXATE AND ITS ROLE IN IMMUNOGENICITY}

P. García ${ }^{1}$, M. González Fernández ${ }^{1}$, M. N. Rivas ${ }^{1}$, J. Duruelo ${ }^{1}$, E. Garmendia ${ }^{1}$, J. Arostegui Lavilla ${ }^{1}$, F. Perez-Ruiz ${ }^{1}$, A. Alonso ${ }^{1}$, C. Modesto ${ }^{1}$, B. A. Blanco Cáceres ${ }^{2} .{ }^{1}$ Hospital Universitario Cruces, Barakaldo, Spain; ${ }^{2}$ Hospital Ramón y Cajal, Madrid, Spain

Background: Immunogenicity against adalimumab leads to loss of response and secondary failure to biologic therapy; however, concomitant use of methotrexate (MTX) seems to reduce the development of anti-drug antibodies (ADAbs) in a dose-dependent manner. Suboptimal adherence to MTX may favour ADAbs appearance.

Objectives: To evaluate the relationship between MTX adherence and ADAbs development.

Methods: Observational study among adult patients with chronic inflammatory arthropathy, followed in a tertiary care centre, who were in treatment with MTX and adalimumab. ADAbs formation in relation to MTX adherence was assessed. Results: 33 patients were included, with a MTX adherence overall mean of 82.13 (12.45\%-100\%, median adherence $92.19 \%)$. Only $9.09 \%(n=3)$ of the patients developed ADAbs, being its MTX adherence mean of $60.95 \%(46.47 \%-70 \%$, median adherence $66.39 \%$ ); ADAbs negative group showed an average MTX adherence of $84.23 \%$ (12.45\%-100\%, median adherence $94.29 \%)$. A statistically significant result $(p<0.05)$ between groups was found.

\begin{tabular}{lccc}
\hline & $\mathbf{n}$ & $\begin{array}{c}\text { Adherence } \\
\text { mean }\end{array}$ & \\
\hline ADAbs $(+)$ & $3(9.09 \%)$ & $60.95 \%$ & $\mathrm{p}<0.05$ \\
ADAbs $(-)$ & $30(90.91 \%)$ & $84.23 \%$ & \\
Total & $33(100 \%)$ & $82.13 \%$ & \\
\hline
\end{tabular}

No statistically significant differences $(\mathrm{p}>0.05)$ involving MTX adherence and its dose were found.

Conclusion: While the sample is small, this study suggests that ADAbs development may be influenced by MTX adherence, thereby promoting adequate MTX adherence should be a priority in the daily practice of every rheumatologist.

References:

[1] World Health Organization. Adherence to long term therapies: evidence for action. 2003
[2] Krieckaert CL, Nurmohamed MT, Wolbink GJ. Methotrexate reduces immunogenicity in adalimumab treated rheumatoid arthritis patients in a dose dependent manner. Annals of the Rheumatic Diseases. 2012;71:1914-1915

[3] Zhang J, Xie F, Delzell E, et al. Impact of biologic agents with and withou concomitant methotrexate and at reduced doses in older rheumatoid arthritis patients. Arthritis Care Res (Hoboken). 2015;67(5):624-632. doi:10.1002/ acr.22510

[4] Jani M, Barton A, Warren RB, Griffiths CE, Chinoy H. The role of DMARDs in reducing the immunogenicity of TNF inhibitors in chronic inflammatory diseases. Rheumatology (Oxford). 2014;53(2):213-222. doi:10.1093/ rheumatology/ket260.

Disclosure of Interests: Paula García: None declared, Marta González Fernández: None declared, Mayra Nathali Rivas: None declared, Javier Duruelo: None declared, Elena Garmendia: None declared, Javier Arostegui Lavilla: None declared, Fernando Perez-Ruiz Consultant of: Amgen

Lilly, Speakers bureau: Amgen, Alberto Alonso: None declared, Consuelo Modesto: None declared, Boris Anthony Blanco Cáceres: None declared DOI: 10.1136/annrheumdis-2020-eular.4803

\section{AB0340 EFFECT OF BARICITINIB ON RANKL SERUM CONCENTRATION IN RHEUMATOID ARTHRITIS PATIENTS}

C. Garufi ${ }^{1}$, F. R. Spinelli ${ }^{1}$, F. Ceccarelli ${ }^{1}$, S. Mancuso ${ }^{1}$, C. Barbati ${ }^{1}$, T. Colasanti ${ }^{1}$, C. Alessandri ${ }^{1}$, F. Conti ${ }^{1} .{ }^{1}$ Sapienza University of Rome, Rome, Italy

Background: RANKL (receptor activator of nuclear factor $\mathrm{KB}$ ligand) and osteoprotegerin, the main regulators of bone metabolism, are involved in osteoblasts/ osteoclasts balance in inflammatory disease, such as Rheumatoid Arthritis (RA). Janus kinase (JAK) inhibitors (baricitinib and tofacitinib) can reduce the progression of structural damage in patients with moderate to severe RA. Previous studies suggest a link between JAK inhibition, production of RANKL and osteoclastogenesis ${ }^{1,2}$

Objectives: to investigate the effect of baricitinib on RANKL serum concentration in unselected RA patients.

Methods: Patients affected by RA according to 2010 ACR criteria, starting treatment with baricitinib as clinically indicated, were consecutively enrolled. Demographic, clinical and laboratory data were collected at baseline (TO) and after three months of therapy (T3). RANKL serum concentration was analyzed by ELISA at the same timepoints. All patients underwent ultrasound (US) examination at TO and T3. According with OMERACT definitions, the presence of synovial effusion, hypertrophy and power Doppler were assessed and scored on a semi-quantitative scale $(0=a b s e n t, 1=$ mild $2=$ moderate, $3=$ severe), obtaining a total US score $(0-198)$, representing the joint inflammatory status (15); erosions were registered. Data were expressed as median (interquartile range); Mann-Whitney and Spearman tests were performed for comparisons and $p$ values $<0.05$ were considered statistically significant.

Results: We prospectively followed up $33 \mathrm{RA}$ patients starting treatmen with baricitinib [M/F 8/25; age 58(9) years; disease duration 165(150) months; $22 / 33$ (67\%) ACPA-anti-citrullinated protein antibody positive $24 / 33$ patients (73\%) RF-rheumatoid factor positive]. After three months of therapy we observed a significant reduction of DAS28 ${ }_{\mathrm{CRP}}, \mathrm{CDAI}$ and SDAI compared to baseline $(p<0.0001)$. The US inflammatory score showed a significant improvement at T3 $(p<0.0001)$. The serum concentration of RANKL showed a significant decrease after three months of therapy from 44 (25.9) to 27.5 (35.3) $\mathrm{pg} / \mathrm{ml}, p=0.0256$ (Figure 1 ). While in $67 \%$ of patients RANKL decreased after treatment, in $33 \%$ of patients no decrease or an increase of RANKL was detected. Those patients showing an increase of RANKL had similar DAS28 ${ }_{\mathrm{CRP}}$, CDAI, SDAI, but had significantly less swollen joints, compared to those in which RANKL decreased $(p=0.0364)$. At baseline, the concentration of RANKL significantly correlated with the swollen joint count $(p=0.0117)$ and ESR $(p=0.0482)$, but not with DAS28 ${ }_{\mathrm{CRP}}$, CDAI, SDAI nor with the US inflammatory score. Nevertheless, the reduction of RANKL was not significantly associated with the achievement of low disease/remission after three months of treatment, with ACPA/RF positivity or the presence of erosions detected by US.

Conclusion: This is the first study demonstrating that baricitinib reduces in vivo the serum levels of RANKL, regardless the correlation with disease activity indices. The discrepancy between the levels of RANKL and the clinical response is in line with previous data in the literature, demonstrating that under treatment with anti-TNF and anti-IL1, the decrease of RANKL did not 
influence the local or systemic inflammatory parameters, even if still preventing bone loss ${ }^{3}$.

References:

[1] LaBranche T P et al. JAK inhibition with tofacitinib suppresses arthritic joint structural damage through decreased RANKL production. Arthritis Rheum 2012

[2] Murakami, KA Jak1/2 inhibitor, baricitinib, inhibits osteoclastogenesis by suppressing RANKL expression in osteoblasts in vitro. PLOS ONE 2017

[3] Stolina M et al. RANKL inhibition by osteoprotegerin prevents bone loss without affecting local or systemic inflammation parameters in two rat arthritis models: comparison with anti-TNFalpha or anti-IL-1 therapies. Arthritis Res Ther 2009

\section{Figure 1. RANKL levels at $\mathrm{TO}$ and $\mathrm{T} 3$}

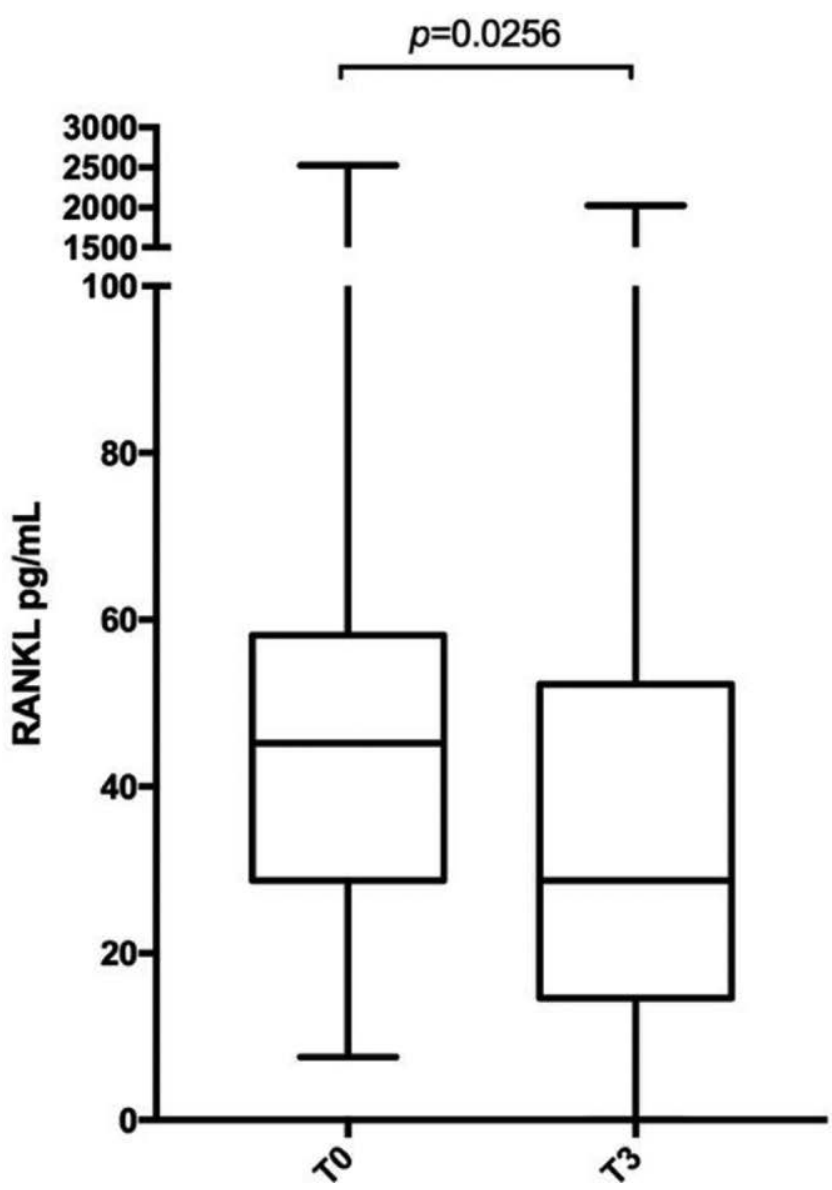

Disclosure of Interests: Cristina Garufi: None declared, Francesca Romana Spinelli Grant/research support from: Pfizer, Consultant of: Novartis, Gilead, Lilly, Sanofi, Celgene, Speakers bureau: Lilly, Fulvia Ceccarelli: None declared, Silvia Mancuso: None declared, cristiana barbati: None declared, Tania Colasanti: None declared, cristiano alessandri Grant/research support from: Pfizer, Fabrizio Conti Speakers bureau: BMS, Lilly, Abbvie, Pfizer, Sanofi DOI: 10.1136/annrheumdis-2020-eular.4399 \begin{tabular}{|l|l}
\hline AB0341 SURVIVAL OF REMISSION OR LOW DISEASE \\
\hline
\end{tabular} ACTIVITY IN RHEUMATOID ARTHRITIS PATIENTS TREATED WITH TOFACITINIB. RESULTS OF RUSSIAN NATIONAL REGISTER

I. Gaydukova ${ }^{1}$, V. Mazurov ${ }^{1}$, A. Lila ${ }^{2}$, A. Baranov ${ }^{3}$, G. Lukina ${ }^{4}$, A. Babaeva ${ }^{5}$, E. Kalinina ${ }^{5}$, T. Salnikova ${ }^{6}$, V. Sorotskaya ${ }^{7}$, R. Samigullina ${ }^{1}$, D. Chakieva ${ }^{1}$, I. Grabovetskaya ${ }^{8}$, I. Marusenko ${ }^{9}$, E. Gaydukova ${ }^{10}$, E. Nasonov ${ }^{2}$.

${ }^{1}$ Mechnikov North-Western State Medical University, St-Petersburg, Russian Federation; ${ }^{2}$ Nasonova Research Institute of Rheumatology, Moscow, Russian Federation; ${ }^{3}$ Yaroslavl State Medical University, Yaroslavl, Russian Federation; ${ }^{4}$ Moscow Clinical Scientific and Practical Centre named after Loginov AS, Moscow, Russian Federation; ${ }^{5}$ Volgograd State Medical University, Volgograd, Russian Federation; ${ }^{6}$ Regional Clinical Hospital, Tula, Russian Federation; ${ }^{7}$ Tula State Medical University, Tula, Russian Federation; ${ }^{8}$ Regional Clinical Hospital, Kaliningrad, Russian Federation; ${ }^{9}$ Petrozavodsk State University, Petrozavodsk, Russian Federation; ${ }^{10}$ Clinical Rheumatological Hospital №25, St. Petersburg, Russian Federation

Background: Tofacitinib is an oral Janus Kinase inhibitor for the treatment of rheumatoid arthritis (RA). The survival of remission or low disease activity (LDA) in RA patients, treated with tofacitinib remain unknown.

Objectives: To evaluate the survival of DAS28 remission or low disease activity in RA patients treated with tofacitinib.

Methods: Data from 102 patients from Russian national register of patients with RA treated with tofacitinib (OREL), achieved DAS28 remission (DAS28<2.6, $\mathrm{n}=92$ ) or LDA (DAS28<3.2, $\mathrm{n}=102$ ) were analyzed. Number of patients with increased disease activity, time of disease activation were registered. Statistical analysis performed with statistical programs SPSS2017 and GraphPadPrizm. p-value $<0.05$ considered as significant.

Results: Baseline characteristics of the patients are presented in table 1.

Table 1. Baseline characteristics of the patients with RA $(n=102)$.

\begin{tabular}{lcc}
\hline Parameter & LDA $(\mathbf{n}=\mathbf{1 0 2})$ & $\begin{array}{c}\text { Remission } \\
(\mathbf{n}=\mathbf{9 2})\end{array}$ \\
\hline Male, $\mathrm{n}(\%)$ & $19(18.6)$ & $15(16.3)$ \\
Age, years (mean \pm SD) & $53.55 \pm 13.46$ & $52.45 \pm 12.56$ \\
Symptoms duration, month (mean \pm SD) & $170 \pm 111.92$ & $169 \pm 110.93$ \\
Positive rheumatoid factor, $\mathrm{n}(\%)$ & $41(40.19)$ & $36(39.13)$ \\
Erosions of hand joints $(\mathrm{X}-$ rays), $\mathrm{n}(\%)$ & $43(42.15)$ & $41(44.56)$ \\
BMl, kg/m ${ }^{2}$ (mean $\left.\pm S D\right)$ & $25.67 \pm 2.22$ & $26.87 \pm 2.19$ \\
Smokers (current and in the past), $\mathrm{n}(\%)$ & $9(8.82)$ & $9(9.78)$
\end{tabular}

$p$-value $\geq 0.05$ for all the differences.

The remission failed in 45 from 92 patients (48.91\%), LDA failed in 65 from 102 of patients $(63.72 \%)$, table 2 .

Table 2. Median for the time of survival of remission or LDA in RA patients treated with tofacitinib.

\begin{tabular}{lcccc}
\hline & $\begin{array}{c}\text { Time, } \\
\text { month }\end{array}$ & & & \\
& Me & $\begin{array}{c}\text { Standard } \\
\text { error }\end{array}$ & $\begin{array}{c}95 \% \text { Confidential } \\
\text { Interval }\end{array}$ & \\
\hline & & & from & To \\
\hline LDA $(n=102)$ & 12.000 & 2.021 & 8.039 & 15.961 \\
Remission $(n=92)$ & 10.312 & 6.000 & 0.796 & 4.440 \\
\hline
\end{tabular}

Proportions of survival of remission or LDA are presented at figure 1 and figure 2 respectively. 